\title{
PELATIHAN DESAIN PETA KONSEP MENGGUNAKAN APLIKASI CMAPTOOLS
}

\author{
Yayan Eryk Setiawan
}

Pendidikan Matematika, Fakultas Keguruan dan Ilmu Pendidikan, Universitas Islam Malang

\begin{abstract}
Abstrak
Peta konsep merupakan bagian penting dalam membuat modul pembelajaran. Akan tetapi guru-guru di MAN Lumajang masih kesulitan dalam membuat peta konsep, dikarenakan tidak memahami cara membuat peta konsep dan tidak mengetahui aplikasi yang dapat digunakan untuk desain peta konsep. Kesulitan-kesulitan ini dapat diatasi dengan memberikan pelatihan desain peta konsep menggunakan aplikasi CmapTools. Aplikasi CmapTools merupakan salah satu aplikasi yang digunakan untuk mendesain peta konsep. Pelatihan ini bertujuan untuk memberikan pemahaman dan kemudahan dalam mendesain peta konsep. Pelatihan ini terbagi menjadi tiga tahap, yaitu praktik, presentasi, dan evaluasi. Hasil pelatihan menunjukkan bahwa pada saat praktik guru-guru antusias dan mampu mendesain peta konsep. Saat presentasi, guru-guru telah menunjukkan pemahaman terhadap peta konsep. Dan dari evaluasi diperoleh respon guru sangat tinggi terhadap pelatihan ini, yaitu sebesar $92,6 \%$.
\end{abstract}

Keywords: Peta Konsep, CmapTools, Pelatihan

\begin{abstract}
Concept maps are an important part of making learning modules. However, teachers at MAN Lumajang still have difficulty in making concept maps because they do not understand how to make concept maps and do not know the applications that can be used to design concept maps. These difficulties can be overcome by providing concept map design training using the CmapTools application. CmapTools application is an application that is used to design concept maps. This training aims to provide understanding and ease in designing concept maps. The training is divided into three stages, namely practice, presentation and evaluation. The results of the training show that during practice the teachers were enthusiastic and able to design concept maps. During the presentation, the teachers showed an understanding of the concept map. And from the evaluation the teacher response was very high towards this training, which was $92.6 \%$.
\end{abstract}

Keywords: Concept Maps, CmapTools, Training

Correspondence author: Yayan Eryk Setiawan, yayaneryksetiawan@unisma.ac.id, Malang, Indonesia

This work is licensed under a CC-BY-NC

\section{PENDAHULUAN}

Undang-Undang Republik Indonesia Nomor 14 Tahun 2005 Tentang Guru dan Dosen mengamanatkan kepada setiap guru dan dosen untuk memiliki dan mengembangkan kompetensi profesional, kompetensi pedagodik, kompetensi kepribadian, dan kompetensi sosial. Kompetensi profesional seorang guru atau dosen ditunjukkan dengan penguasaan terhadap materi dan pembelajarannya. Salah satu wujud dari penguasaan terhadap materi adalah mampu membuat modul pembelajaran yang 
baik. Modul pembelajaran merupakan bahan ajar yang disusun secara mandiri oleh guru atau secara berkelompok dengan tujuan untuk mencapai kompetensi-kompetensi yang telah ditetapkan dalam kurikulum. Bagian inti dari modul pembelajaran antara lain: kompetensi dasar, tujuan pembelajaran, peta konsep, materi pembelajaran, latihan, dan umpan balik.

Akan tetapi hasil survey yang dilakukan oleh pengabdi di MAN Lumajang tentang kesulitan guru-guru dalam menyusun modul pembelajaran menunjukkan bahwa kesulitan guru-guru di MAN Lumajang adalah membuat peta konsep. Kesulitan guru dalam membuat peta konsep yaitu tidak memahami cara membuat peta konsep dan tidak mengetahui aplikasi yang dapat digunakan untuk membuat peta konsep. Akibat dari kesulitan ini, guru membuat peta konsep menggunakan Microsoft Word dan ada guru yang hanya mengambil peta konsep dari internet secara copy paste. Ini artinya, permasalahan guru-guru di MAN Lumajang adalah tidak mengetahui cara membuat peta konsep dan tidak mengetahui aplikasi yang digunakan untuk mendesain peta konsep dengan mudah.

Masalah-masalah guru ini harus di atasi. Hal ini dikarenakan peta konsep tersebut memiliki peran penting dalam memetakan materi apa saja yang harus dimuat dalam modul pembelajaran. Apabila terdapat materi yang tidak termuat dalam modul pembelajaran, maka akan berdampak pada kurangnya pengetahuan siswa. pada akhirnya akan menurunkan prestasi belajar siswa. Hasil penelitian menunjukkan bahwa salah satu faktor penyebab siswa melakukan kesalahan adalah tidak pernah mendapatkan materi dari soal yang ditanyakan (Setiawan, 2020b, 2020e, 2020a, 2020c). Selain itu, peta konsep ini dapat digunakan sebagai pemandu dalam pembelajaran (Setiawan, 2019b, 2019a; Setiawan \& Syaifuddin, 2020a), sehingga memudahkan guru dalam membelajarkan suatu materi. Hasil penelitian menunjukkan bahwa pembelajaran yang dilakukan oleh guru dapat mempengaruhi prestasi belajar siswa (Setiawan, 2020d; Setiawan, Purwanto, Parta, \& Sisworo, 2020; Setiawan \& Syaifuddin, 2020b). Oleh karena itu masalah guru tidak mengetahui cara mendesain peta konsep penting untuk diatasi, agar pembelajaran yang dilakukan dapat berjalan lancar dan dapat meningkatkan prestasi siswa.

Salah satu solusi yang diambil oleh pengabdi untuk mengatasi masalah kesulitan guru dalam mendesain peta konsep adalah dengan memberikan pelatihan desain peta konsep menggunakan aplikasi CmapTools. Aplikasi CmapTools merupakan salah satu aplikasi yang dikembangkan untuk memberikan kemudahan dalam mendesain peta konsep (Setiawan, 2019a, 2019b). Lebih lanjut Novak dan Canas dalam (Setiawan, 2019b) mengatakan bahwa aplikasi CmapTools lebih dari sekedar memfasilitasi pembangunan peta konsep yang mudah digunakan, CmapTools juga memanfaatkan internet untuk memungkinkan pengguna berkolaborasi secara lokal maupun jarak jauh dalam pembuatan peta konsep. Kemudahan dalam penggunaan aplikasi CmapTools dalam mendesain peta konsep adalah melalui operasi drag-and-drop. Oleh sebab itu, kemudahan dalam menggunakan aplikasi Cmaptools ini yang memungkinkan guru dapat mendesain peta konsep dengan mudah.

Sebelum solusi yang ditawarkan di implementasikan di MAN Lumajang. Pengabdi melakukan penawaran kepada guru-guru untuk diadakan pelatihan tentang desain peta konsep menggunakan aplikasi CmapTools. Hasil penawaran menunjukkan bahwa 40 guru menghendaki untuk diadakan pelatihan desain peta konsep dengan menggunakan aplikasi CmapTools. Selain itu wakil kepala bagian kurikulum 
mengatakan bahwa guru-guru belum pernah mendapatkan pelatihan desain peta konsep, sehingga pelatihan ini sangat dibutuhkan untuk meningkatkan profesional guru.

Berdasarkan uraian yang sudah dijelaskan tersebut, maka diperoleh bahwa masalah yang dihadapi oleh mitra adalah kesulitan dalam mendesain peta konsep. Alternatif solusi yang ditawarkan adalah melalui pelatihan desain peta konsep menggunakan aplikasi CmapTools. Aplikasi CmapTools sangat mudah untuk digunakan dalam mendesain peta konsep. Oleh karena itu, tujuan utama dari pengabdian yang berupa pelatihan ini adalah membekali guru-guru tentang cara mendesain peta konsep yang benar dengan menggunakan aplikasi CmapTools. Hasil dari pelatihan ini adalah guru-guru dapat mendesain peta konsep dengan benar dan mudah. Dengan demikian diharapkan modul pembelajaran yang disusun oleh guru menjadi lebih lengkap, sehingga memudahkan guru dalam melakukan pembelajaran dan membantuk siswa untuk mempelajari materi yang lengkap.

\section{METODE PELAKSANAAN}

Pengabdian kepada masyarakat ini dilaksanakan di MAN Lumajang yang terletak di Kabupaten Lumajang Provinsi Jawa Timur. Kegiatan pengabdian ini dilaksanakan pada periode September 2019 sampai Maret 2020. Kegiatan pengabdian ini diawali dengan melakukan analisis situasi dari mitra, yaitu MAN Lumajang. Setelah melakukan analisis situasi, pengabdi mengajukan proposal pengabdian kepada Lembaga Penelitian dan Pengabdian Kepada Masyarakat (LPPM) Universitas Islam Malang. Setelah proposal pengabdian disetujui, maka dilanjutkan dengan menyusun jadwal pengabdian dan pembuatan modul pengabdian.

Setelah modul pengabdian selesai dibuat, pengabdi melanjutkan dengan mengonfirmasi mitra untuk menentukan waktu pelatihan dan menanyakan jumlah peserta pelatihan yang akan diikutkan. Jumlah peserta pelatihan sebanyak 40 guru dan tanggal pelatihan adalah 14 Desember 2019. Peserta pelatihan yang terdiri dari 40 guru tersebut sebagian kecil adalah guru senior dan sebagian besar adalah guru-guru baru. Guru-guru ini memiliki semangat yang tinggi dalam mengembangkan kompetensinya.

Metode kegiatan pengabdian yang dipilih adalah pelatihan. Tujuan utama dari pelatihan ini adalah membekali guru-guru kemampuan untuk dapat mendesain peta konsep dengan menggunakan aplikasi CmapTools. Kegiatan pelatihan ini terdiri dari tiga tahap, yaitu praktik, presentasi, dan evaluasi (lihat Gambar 1).

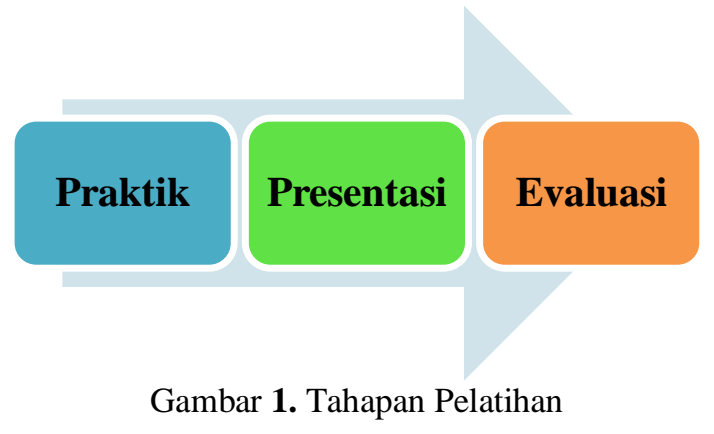

Tahap pertama adalah praktik mendesain peta konsep yang langsung dibimbing oleh pengabdi. Guru-guru secara langsung membuat peta konsep dan pengabdi mempresentasikan langkah-langkah desain peta konsep di depan kelas yang diikuti 
secara langsung oleh guru-guru untuk mendesain peta konsep. Desain peta konsep menggunakan aplikasi CmapTools ini menggunakan buku panduan penggunaan CmapTools untuk desain peta konsep yang ditulis oleh pengabdi (Setiawan, 2019a). Dalam tahap pertama ini, juga secara langsung dilakukan diskusi dan Tanya jawab.

Tahap kedua adalah presentasi. Setelah guru-guru selesai mendesain peta konsep dengan menggunakan aplikasi CmapTools, maka perwakilan dari beberapa guru diminta untuk mempresentasikan hasil desain peta konsep tersebut. Sedangkan guru yang lain memperhatikan dan menilai peta konsep yang dipresentasikan. Tujuan dari tahap presentasi ini adalah untuk memahami kelebihan dan kekurangan dari peta konsep yang telah dibuat oleh guru.

Tahap ketiga adalah evaluasi. Setelah kegiatan pelatihan selesai, peserta diminta untuk mengisi angket evaluasi keberhasilan pengabdian ini. Angket ini secara umum terdiri dari: (1) isi materi, (2) pemaparan materi, (3) diskusi/tanya jawab, dan (4) praktik kerja individu. Masing-masing pernyataan dalam angket tersebut menggunakan pilihan: sangat tidak setuju (STS), tidak setuju (TS), normal (N), setuju (S), dan sangat setuju (SS). Masing-masing pilihan diberi skor 1, 2, 3, 4, 5. Terdapat 17 item pernyataan yang harus diisi oleh guru, sehingga diperoleh skor minimum adalah 17 dan skor maksimum adalah 85. Dari skor maksimum dan minimum ini akan ditentukan kategori keberhasilan pelatihan ini dengan menggunakan interval sangat rendah, rendah, sedang, tinggi, dan sangat tinggi. Penentuan interval tersebut menggunakan persentase, yaitu: sangat rendah (0-20\%), rendah (20\%-40\%), sedang (40\%-60\%), tinggi (60\%-80\%), dan sangat tinggi (80\%-100\%). Dari persentase ini diperoleh kategori keberhasilan pelatihan yang dapat dilihat dalam Tabel 1 berikut.

Tabel 1. Kategori Keberhasilan Pelatihan

\begin{tabular}{ccc}
\hline Skor & Kategori & Keberhasilan Pelatihan \\
\hline $0 \leq x \leq 17$ & Sangat rendah & Sangat tidak berhasil \\
$17<x \leq 34$ & Rendah & Tidak berhasil \\
$34<x \leq 51$ & Sedang & Kurang berhasil \\
$51<x \leq 68$ & Tinggi & Berhasil \\
$68<x \leq 85$ & Sangat Tinggi & Sangat berhasil \\
\hline
\end{tabular}

Dari kategori yang diperoleh akan dinterpretasikan secara kualitatif untuk menjelaskan makna dari kategori yang diperoleh. Jika hasil angket menunjukkan kategori tinggi atau sangat tinggi, maka pelatihan ini berhasil dalam membekali guruguru dalam mendesain peta konsep. Akan tetapi jika hasil angket berada pada kategori sedang, rendah, atau sangat rendah, maka pelatihan kurang berhasil.

\section{HASIL DAN PEMBAHASAN}

Sebelum kegiatan pelatihan ini dimulai, kegiatan pelatihan ini dibuka oleh Kepala MAN Lumajang (lihat Gambar 2). Tujuan pembukaan yang dilakukan oleh kepala MAN Lumajang ini adalah memberikan motivasi dan dukungan kepada guru-guru agar sungguh-sungguh dalam mengikuti pelatihan dan memiliki pikiran terbuka dalam menerima informasi-informasi perkembangan teknologi dan ilmu pengetahuan. Dengan adanya dukungan dan sambutan kepala MAN Lumajang ini, guru-guru menjadi lebih bersungguh-sungguh dalam mengikuti pelatihan, karena guru-guru termotivasi. Oleh 
sebab itu, dalam setiap pelatihan hendaknya memberikan kesempatan kepada pimpinan untuk memberikan sambutan, karena ini berdampak positif dalam pelatihan.

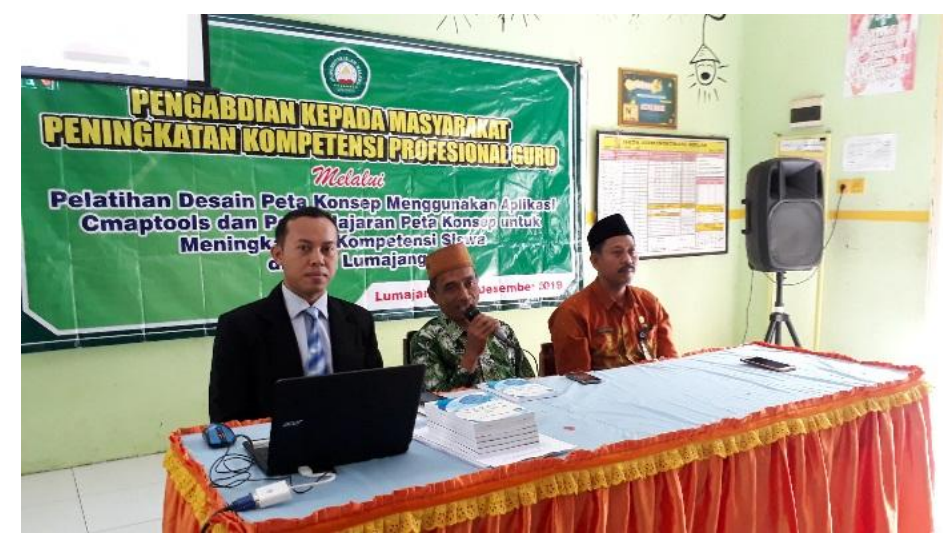

Gambar 2. Pembukaan Pelatihan Oleh Kepala MAN Lumajang

Setelah sambutan dari kepala MAN Lumajang selesai, kegiatan berikutnya langsung pelatihan. Hasil dari pelatihan ini akan dipaparkan sesuai dengan tahapantahapan pelatihan, yaitu praktik, presentasi, dan evaluasi. Tahap pertama adalah praktik. Tahap praktik ini berlangsung sekitar 4 jam. Dalam tahapan ini, setiap guru bekerja secara mandiri untuk mendesain peta konsep. Dengan bimbingan pengabdi, para guru langsung menginstall aplikasi CmapTools pada laptop masing-masing. Setelah semua guru berhasil menginstal aplikasi CmapTools, berikutnya adalah mendesain peta konsep menggunakan aplikasi CmapTools yang secara langsung dipandu dan dibimbing oleh pengabdi (lihat Gambar 3).

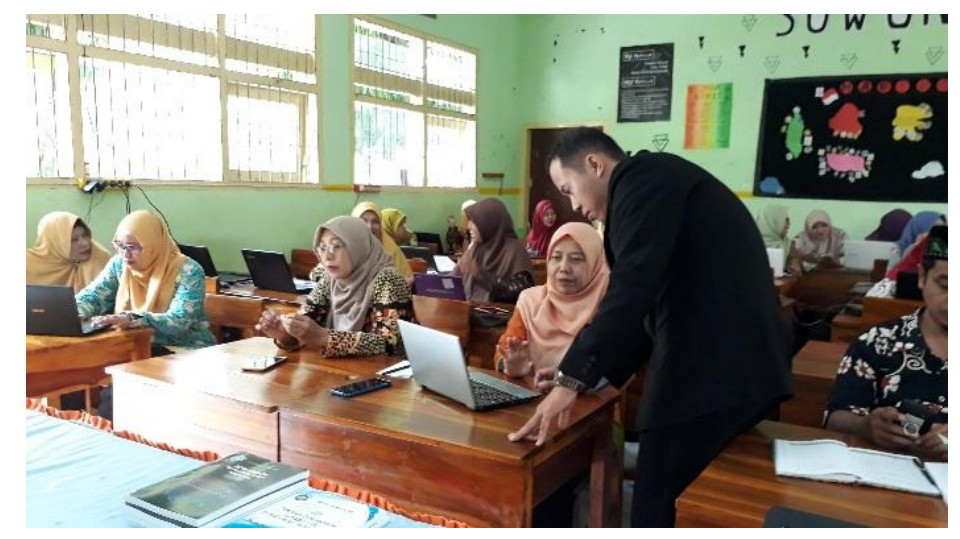

Gambar 3. Pembimbingan Desain Peta Konsep oleh Pengabdi

Pada sesi praktik ini tampak guru-guru semangat untuk mendesain peta konsep dari salah satu materi yang mereka belajarkan di sekolah. Pada sesi praktik ini juga secara langsung diberikan kesempatan untuk bertanya tentang kesulitan yang guru-guru hadapi saat mendesain peta konsep. Kebanyakan kesulitan mendesain peta konsep dengan menggunakan aplikasi CmapTools ini antara lain: (1) guru kesulitan saat menginstal aplikasi, karena membutuhkan tahapan-tahapan menginstal, (2) guru kesulitan mengatur kerapian dari peta konsep yang dibuat, karena baru menggunakan aplikasi (3) guru-guru masih ada yang tidak menggunakan kata penghubung antara 
konsep, dan (4) guru juga kesulitan membuat presentasi dari peta konsep. Dalam sesi praktik ini juga ditemukan bahwa guru-guru yang berhasil mendesain peta konsep dengan bagus adalah guru-guru yang betul-betul memperhatikan pengabdi saat memandu pembuatan peta konsep di depan dan guru-guru yang aktif bertanya dan meminta pengabdi untuk membimbing pembuatan peta konsep.

Tahap kedua adalah presentasi. Pengabdi meminta perwakilan dari guru untuk mempresentasikan hasil peta konsep yang berhasil didesain di depan guru-guru lainnya. Ada tiga guru yang secara sukarela mencoba mempresentasikan hasil peta konsep mereka. Guru pertama yang mempresentasikan hasil desain peta konsep adalah guru Fisika (lihat Gambar 4).

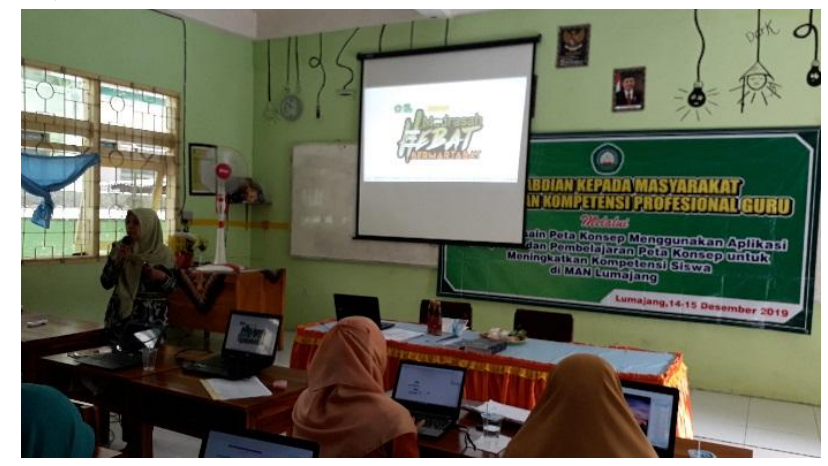

Gambar 4. Presentasi Hasil Desain Peta Konsep Oleh Guru

Setelah presentasi selesai dilaksanakan, guru diminta untuk menyebutkan apa keunggulan dari desain peta konsep menggunakan aplikasi CmapTools ini. Guru menyebutkan bahwa kelebihaanya adalah: (1) mudah membuat peta konsep, (2) peta konsep dapat dipresentasikan secara runtut, (3) aplikasi baru ini sangat cocok di terapkan di MAN Lumajang. Akhirnya secara keseluruhan guru-guru senang dengan adanya pelatihan ini yang dapat mengatasi masalah desain peta konsep. Contoh peta konsep yang berhasil di desain oleh Guru dapat dilihat dalam Gambar 5. Dalam kegiatan presentasi ini, guru-guru yang lain memberikan masukan terhadap peta konsep yang dibuat, yaitu: (1) hendaknya peta konsep diberi contoh agar lebih paham, (2) hendaknya diberi definisi dari konsep, dan (3) menjelaskan keterhubungan antar konsep.

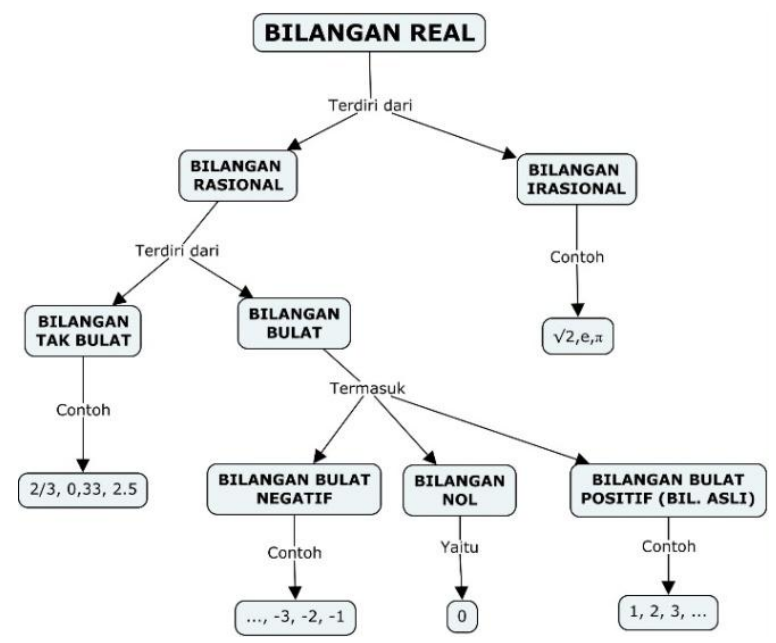

Gambar 5. Contoh Peta Konsep Guru Matematika 
Setelah kegiatan praktik dan presentasi selesai, maka kegiatan ini diakhiri dengan pemberian angket evaluasi terhadap kegiatan pelatihan ini. Tujuan dari evaluasi kegiatan pengabdian ini adalah untuk mengetahui sejauh mana keberhasilan pelatihan ini. Terdapat 27 guru yang berpartisipasi mengisi angket. Dengan menggunakan kategori keberhasilan pelatihan dalam Tabel 1, maka diperoleh persentase banyaknya guru dari masing-masing kategori dapat dilihat dalam Tabel 2.

Tabel 2. Persentase Banyaknya Guru

\begin{tabular}{lll}
\hline \multicolumn{1}{c}{ Kategori } & Jumlah guru & Persentase \\
\hline Sangat rendah & 0 & $0 \%$ \\
Rendah & 0 & $0 \%$ \\
Sedang & 0 & $0 \%$ \\
Tinggi & 2 & $7,4 \%$ \\
Sangat Tinggi & 25 & $92,6 \%$ \\
\hline
\end{tabular}

Dari Tabel 2 diperoleh bahwa sebanyak 25 guru memberikan respon yang sangat tinggi terhadap pelatihan ini. Dari respon yang sangat tinggi ini dapat dikatakan bahwa pelatihan memiliki tingkat keberhasilan 92,6\%. Keberhasilan pelatihan ini ditunjukkan dengan guru telah menguasai cara mendesain peta konsep dengan menggunakan aplikasi CmapTools. Keberhasilan pelatihan ini terbagi menjadi 4 pokok kegiatan secara umum, yaitu: materi, pemaparan materi, diskusi/tanya jawab, serta praktik kerja individu. Masing-masing keberhasilan dari 4 pokok kegiatan pelatihan ini dapat dilihat dalam Tabel 3.

Tabel 3. Keberhasilan Pelatihan Desain Peta Konsep Menggunakan Aplikasi CmapTools

\begin{tabular}{|c|c|}
\hline Pokok kegiatan & Keberhasilan \\
\hline \multirow{5}{*}{ Materi } & Materi terorganisasi dengan baik dan mudah dimengerti. \\
\hline & Materi relevan dan sesuai yang diharapkan. \\
\hline & Materi sesuai dengan perkembangan teknologi. \\
\hline & Materi menarik untuk dipelajari. \\
\hline & Materi sudah mencukupi untuk mampu mendesain peta konsep. \\
\hline \multirow{3}{*}{$\begin{array}{l}\text { Pemaparan } \\
\text { materi }\end{array}$} & Pengabdi sangat memahami materi. \\
\hline & Alokasi waktu sudah mencukupi. \\
\hline & Pengabdi mempresentasikan materi dengan baik dan mudah dimengerti. \\
\hline \multirow{2}{*}{$\begin{array}{l}\text { Diskusi dan } \\
\text { Tanya jawab }\end{array}$} & Diskusi dan Tanya jawab menambah pemahaman tentang materi. \\
\hline & Pengabdi memberikan jawaban dengan baik. \\
\hline \multirow{3}{*}{$\begin{array}{l}\text { Praktik kerja } \\
\text { individu }\end{array}$} & Panduan Praktik menggunakan aplikasi telah disediakan dengan baik. \\
\hline & Pengabdi telah memfasilitasi dengan baik. \\
\hline & Alokasi waktu praktik telah mencukupi. \\
\hline
\end{tabular}

Sedangkan terdapat 2 guru dalam kategori Tinggi. Dua guru tersebut menyatakan bahwa waktu yang diberikan kurang cukup untuk mendesain peta konsep dan terlalu cepat dalam penyampaian materi. Tetapi meskipun terdapat dua guru dengan kategori tinggi, pelatihan ini dapat dikatakan berhasil. Salah satu peserta yang juga merupakan wakil kurikulum menyatakan bahwa keberhasilan pelatihan ini adalah $95 \%$ guru-guru sudah mampu mendesain peta konsep dengan mudah.

\section{SIMPULAN}

Berdasarkan hasil pengabdian diperoleh bahwa kegiatan pelatihan desain peta konsep menggunakan aplikasi CmapTools ini telah berhasil membekali guru-guru 
tentang cara-cara mendesain peta konsep dengan menggunakan aplikasi CmapTools. Tingkat keberhasilan pelatihan ini didukung oleh respon guru dalam kategori sangat tinggi sebesar 92,6\%. Faktor-faktor pendukung keberhasilan pelatihan ini antara lain: (1) adanya motivasi dan dukungan dari kepala MAN Lumajang terhadap kegiatan pelatihan ini, (2) adanya kesungguhan dari pemateri atau pengabdi untuk memberikan pelatihan secara maksimal, (3) adanya keterbukaan, semangat dan respon positif dari guru-guru untuk menerima dan mempelajari aplikasi CmapTools, (4) adanya penguasaan materi oleh pemateri atau pengabdi dengan baik, dan (5) pemilihan waktu pelaksanaan kegiatan yang tepat, yaitu sebelum pembelajaran awal semester atau awal tahun dimulai, dan (6) setiap guru memiliki laptop serta daya listrik dan perlengkapan kabel terpenuhi.

Saran untuk pengabdian berikutnya adalah dengan memberikan pelatihanpelatihan desain peta konsep menggunakan aplikasi CmapTools ke guru-guru di jenjang pendidikan dasar dan menengah pertama untuk mengetahui relevansi dari aplikasi ini di berbagai jenjang pendidikan. Saran untuk pemateri atau pengabdi dalam melakukan pengabdian yang berupa pelatihan ke guru-guru adalah secara langsung melakukan kegiatan praktik, karena guru-guru lebih senang jika dalam pelatihan langsung praktik dan ada hasil yang diperoleh daripada hanya berbasis pada teori saja. Penyampaian teori dapat dilakukkan bersamaan dengan praktik. Selain itu, kegiatan secara langsung akan meminimkan waktu yang dibutuhkan.

\section{DAFTAR PUSTAKA}

Setiawan, Y. E. (2019a). Panduan Penggunaan CmapTools untuk Desain Peta Konsep. Lumajang: CV. Al-Mukmin Yes.

Setiawan, Y. E. (2019b). Peta Konsep dalam Pembelajaran Matematika. Lumajang: CV. Al-Mukmin Yes.

Setiawan, Y. E. (2020a). Analisis Kemampuan Siswa dalam Pembuktian Kesebangunan Dua Segitiga. Al-Khwarizmi: Jurnal Pendidikan Matematika Dan Ilmu Pengetahuan Alam, 8(1), 23-38. https://doi.org/http://dx.doi.org/10.24256/jpmipa. v8i1.80

Setiawan, Y. E. (2020b). Analisis Kesalahan Siswa dalam Menggeneralisasi Pola Linier. Jurnal Nasional Pendidikan Matematika, 4(2), 180-194. https://doi.org/http://dx.doi.org/10.33603/jnpm.v4i2.3386

Setiawan, Y. E. (2020c). Analisis Kesalahan Siswa dalam Menilai Kebenaran Suatu Pernyataan. Jurnal Didaktik Matematika, 7(1), 13-31. https://doi.org/10.24815/ jdm.v7i1.14495

Setiawan, Y. E. (2020d). Sistem Pendukung Pengambilan Keputusan Rekrutmen Guru Menggunakan Logika Fuzzy Tahani. Barekeng: Jurnal Ilmu Matematika Dan Terapan, 14(2), 259-272. https://doi.org/10.30598/barekengvol14iss2pp259-272 
Setiawan, Y. E. (2020e). The Thinking Process of Students Using Trial and Error Strategies in Generalizing Linear Patterns. Numerical: Jurnal Matematika Dan Pendidikan Matematika, https://doi.org/10.25217/numerical.v4i1.839

Setiawan, Y. E., Purwanto, Parta, I. N., \& Sisworo. (2020). Generalization Strategy of Linear Patterns From Field-Dependent Cognitive Style. Journal on Mathematics Education, 11(1), 77-94. http://doi.org/10.22342/jme.11.1.9134.77-94

Setiawan, Y. E., \& Syaifuddin. (2020a). Pelatihan Desain Peta Konsep dan Pembelajarannya: Pengabdian Kepada Masyarakat. Lumajang: CV. AlMukmin Yes.

Setiawan, Y. E., \& Syaifuddin. (2020b). Peningkatan Kompetensi Profesionalitas Guru Melalui Pelatihan Desain Pembelajaran Peta Konsep. Jurnal Pengabdian Kepada Masyarakat, 26(3), 148-153. http://dx.doi.org/10.24114/jpkm.v26i3.16377 